\title{
Casualties of war
}

\author{
Fiona Godlee editor in chief, The BMJ
}

The strike by England's junior doctors - the first in 40 years-is both historic and deeply sad. Doctors have taken this action reluctantly, in protest against proposed changes to their contract that they believe threaten morale, recruitment, and the safety of patients. Although reluctant to strike, junior doctors were nearly unanimous in deciding to do so. They have wide support among senior colleagues, other health professionals, and, as reported earlier this week, the public (doi:10.1136/bmj.i188).

England's two most senior doctors- the chief medical officer, Sally Davies, and NHS England's medical director, Bruce Keogh-have spoken out against the strike. This should come as no surprise. Both are public servants with legal and statutory accountabilities. Keogh's letter just after the decision to strike has created most upset, initially for his choice of words and now because of revelations that the letter was reviewed before sending by the Department of Health (doi:10.1136/bmj.i130).

Margaret McCartney sympathises with these concerns (doi:10. $1136 / \mathrm{bmj} .1141)$. She says that we need to be assured that Keogh's views were arrived at entirely independently. Nigel Hawkes disagrees (doi:10.1136/bmj.i181). When governments face acute difficulties, it's their job to make sure that all the spokespeople they can influence are speaking with the same voice, he says. "All's fair in love and war, and this is war," Hawkes concludes.

Paradoxically, the very thing the government wants to achieve, a seven day service, has become the first casualty. Work was well under way by 2013 to understand the problem at weekends, gather new evidence of its scale, define the main areas most in need, and build a professional consensus around clinical standards for assessing the care provided at weekends. Led by Keogh, the process was begun and driven by clinicians. Patients were closely involved. By the time of the general election in
May last year the standards were about to be rolled out, focusing initially on urgent and emergency care. The relevant royal colleges were fully on board.

As I describe in a Feature article (doi:10.1136/bmj.i187), it has taken the government only six months to derail this carefully constructed consensus. With no money to fund its unrealistic and often changing definition of seven day services, it now needs scapegoats and fall guys. Junior doctors are one vulnerable group. If nurses were next, this would lead to flight rather than fight, their new leader says (doi:10.1136/bmj.h6796). To avoid piecemeal attrition, the professions must stand together.

We should also support Keogh rather than allowing the government to drive a wedge between him and the rest of the profession. Over many years in different roles he has shown courage, integrity, and commitment to patients, doctors, and the NHS. His departure would be an individual injustice and a collective loss.

There are other potential casualties of this war. The biggest may be the NHS itself. By picking a fight with doctors, the government has created a damaging and unnecessary distraction from the real challenges that the NHS faces. Norman Lamb has called for a commission to openly debate and decide the future of the NHS (doi:10.1136/bmj.i127). I support his call.

Competing interests: The BMJ has worked with NHS England on conferences for junior doctors (Agents for Change, fmlm.ac.uk), and one of the Faculty of Medical Leadership and Management clinical fellows has a joint appointment, spending half the time at NHS England and half at The BMJ.

Cite this as: BMJ 2016;352:1203

๑ BMJ Publishing Group Ltd 2016 